\title{
SWAZILAND
}

\section{DEMOGRAFIESE EN ETNOGRAFIESE ASPEKTE}

\section{A. ALGEMEEN DEMOGRAFIES}

Samestelling en groei.

Swaziland verskil van die ander twee Britse Hoëkommissarisgebiede, Basoetoland en Betsjoeanaland, ook daarin dat sy bevolking meer gemengd is deur die aanwesigheid van 'n aansienlike min of meer gevestigde blanke bevolking. Die verskynsel hou verband met die posisie ten opsigte van grondverdeling en -besit. Tabel $n r .1$ gee 'n beeld van die bevolkingsamestelling volgens ras en van die bevolkingsgroei.

TABEL 1.1)

Geboorteplek

\begin{tabular}{lrrrrrr} 
Groep & 1904 & 1921 & 1946 & 1956 & 1962 & $\%$ \\
\hline $\begin{array}{lrrrrr}\text { Swaziland } \\
\text { Bantoe }\end{array}$ & - & 108,441 & 175,075 & 225,166 & 250,400 & \\
Blank & - & 769 & 998 & 1,130 & 1,520 & \\
Gekleurd & - & 345 & 625 & 1,102 & 1,570 & \\
\hline Elders & & & & & & \\
Bantoe & - & 1,854 & 3,194 & 8,048 & 19,600 & \\
Blank & - & 1,436 & 3,203 & 4,789 & 6,520 & \\
Gekleurd & - & 106 & 120 & 276 & 690 & \\
\hline Subtotaal & & & & & & \\
Bantoe $\left.^{2}\right)$ & 84,529 & 110,295 & 181,269 & 233,214 & 270,000 & 96.3 \\
Blank $^{3}$ ) & 890 & 2,205 & 3,201 & 5,919 & 8,040 & 2.9 \\
Gekleurd $\left.^{3}\right)$ & 72 & 451 & 745 & 1,378 & 2,260 & 0.8 \\
\hline Totaal $^{2}$ & 85,491 & 110,295 & 181,269 & 233,214 & 280,300 & 100 \\
\hline
\end{tabular}

Uit hierdie gegewens blyk dit dat die nie-inheemse elemente, t.w. Blankes, Kleurlinge (insluitende 10 Indiërs) en

1) Gt. Britain: Swaziland. Report for 1962. H.M.S.O. 1963.

2) Volgens skatting, Desember 1962.

3) Sensus, April-Mei 1962. 
gewas het. Dit moet waarskynlik veral in verband gesien word met die pogings tot ekonomiese ontwikkeling van die Protekbuite Swaziland gebore Bantoes veral sedert 1946 sterk aantoraat sedert die Tweede Wêreldoorlog. Die verhouding van die rassegroepe is, globaal gesproke, 1 Kleurling tot 3 Blankes tot 96 Bantoes.

\section{Bantoes.}

Die 270,000 Bantoes sluit 10,300 persone in wat tydelik buite die gebied verkeer. Dit word bereken dat van hierdie totaal tussen 220,798 en 241,600 Swazi's is. Die res word saamgestel deur Zoeloes, Tonga's, Sjangaans en andere. Volgens die 1962-skatting was 250,400 in Swaziland gebore en 19,600 buite die gebied. Hierdie syfers kan nie sonder meer betrek word op die getalle Swazi's en nie-Swazi's nie, omdat Swazikinders buite Swaziland gebore word en van die immigranteBantoes binne die gebied woon met hulle vroue en gesinne.

Diegene wat buite Swaziland geboortig is, kan soos volg ingedeel word:*

R.S.A.

Mosam 3,920

Elders:

Noord- en Suid-Rhodesië ................................. 580

Njassaland ........................................................... 640

Basoetoland ..................................................... 270

Betsjoeanaland ........................................................ 60

Tanganyika ..................................................... 60

Res van Afrika en elders .............................. $110 \quad 1,720$

Totaal

* Aangepas uit Swaziland Report, 1962, bll. 12 en 13.

Teenoor die 254,100 Swazi's word die Zoeloes op 7,600, die Tonga's en Sjangaans op 3,500, die Sotho op 1000 en die Xhosa en verwante stamme op 1000 geskat, met 2,800 ongespesifiseerd. Hoewel die oorgrote meerderheid Siswati praat, kan 24,300 Bantoes (9\%) hulle in Engels behelp en minder as 800 is Afrikaans magtig. Etlike honderde ken Portugees. 


\section{Blankes}

Van die 8,040 blankes (1962) is 1520 in Swaziland gebore en 6,520 daarbuite. Laasgenoemde groep is van die volgende lande afkomstig:*

R.S.A. ............................................................................................... 4,420

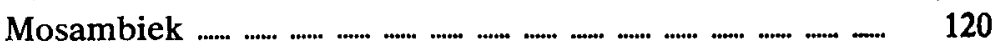

Britse Eilande:

Skotland ............................................................... 140

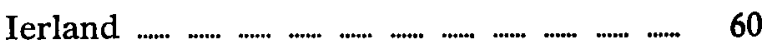

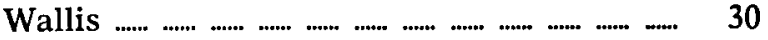

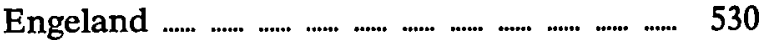

Elders:

Noord- en Suid-Rhodesië ............................ 130

Njassaland .............................................................. 10

Basoetoland ....................................................... 30

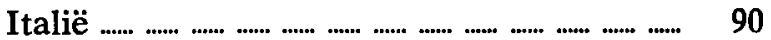

Oos- en Wes-Duitsland .................................. $\quad 80$

V.S.A. ...................................................................... 80

Betsjoeanaland ...................................................... 10

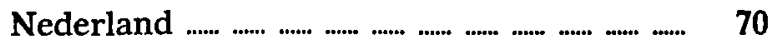

Kenia ..................................................................... 50

Indië en Pakistan ............................................. 40

Portugal .............................................................. 340

Kanada .................................................................... 30

Noorwe ë ............................................................... 30

Australië ................................................................ 25

Rusland/Oosseestate .......................................... 25

Res van Europa ................................................... $\quad 80$

Ongespesifiseerd ........................................... $100 \quad 1,220$

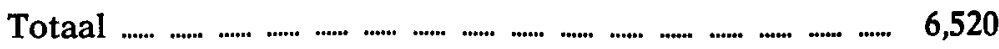

* Verwerk uit Swaziland Report, 1962, bl. 13. 
Volgens nasionaliteit kan die blankes (persone bo 21 jaar) soos volg ingedeel word:*

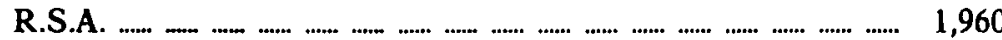

S.A. en Ver. Koninkryk ................................................ 600

Portugal ........... .............................................................................. 300

Ander ................................................................................. 500

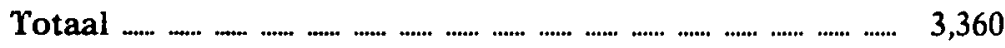

Slegs ongeveer $20 \%$ van die blanke-bewoners is derhalwe in Swaziland gebore, sodat hierdie sektor van die bevolking met 'n groot mate van reg as 'n immigrantegroep beskou kan word. Dit blyk verder uit die syfers van tabel nr. 1 (die skerpste styging in getalle kom voor ná 1946) en in die volgende ontleding van immigrasiesyfers. Gedurende die afgelope 7 jaar was die gemiddelde jaarlikse toevloei 1180 , met 920 emigrante per jaar en 'n wins van 260. Sedert 1953 is die immigrasietempo versnel en die -omvang vergroot, sodat daar in 1962 1700 blankes in Swaziland was vir korter as 2 jaar (d.w.s. 'n wins van ongeveer 850 per jaar) en 2800 korter as 4 jaar (d.w.s 'n wins van 700 per jaar). Hierdie syfers dui ook op 'n toenemende tempo. Van die immigrante wat die gebied tussen 1955 en 1958 binne gekom het, het $45 \%$ minder as een jaar aangebly, $56 \%$ minder as 2 en $72 \%$ minder as 4 jaar. Hulle gemiddelde termyn van verblyf was $15-16$ maande. Die meeste was betrokke by korttermyn-kontrakte by die nuwe nywerheidsontwikkeling. In 1962 het 2364 persone tydelike en 167 persone permanente verblyfpermitte ontvang.

Van die blankes is 2,460 (31\%) Afrikaanssprekend. Hulle is veral saamgetrek in die Goedgegungebied en suid van die Usuturivier, waar hulle $60 \%$ en $67 \%$ resp. van die blankebevolking uitmaak. In die ander dorpe is die persentasie Afrikaanssprekendes ongeveer 22\%. Verder het 450 blankes Portugees as huistaal, 70 Italiaans, 50 Duits, 50 Nederlands en 20 Noorweegs.

Kleurlinge en Indiërs.

Vanweë die opvallend geringe getal Indiërs (10 in 1962) word hulle onder die Kleurlinge gegroepeer. Ongeveer $70 \%$ van die Kleurlinge (1570) is in Swaziland gebore teenoor 690

* Ontleen aan Swaziland Report, 1962, bl. 13. 
afkomstig van buite die gebied. Hulle verteenwoordig dus naas die natuurlike aanwas van Kleurlinggesinne blykbaar ook 'n sterk aanwas uit Kleurling-Bantoe-, Kleurling-Blanke- en Blanke-Bantoevermenging. Van die 690 geboortig buite Swaziland het die oorgrote meerderheid die Republiek as land van herkoms (640); 30 is in Mosambiek gebore en 20 elders; 220 Kleurlinge (bo 21 jaar) is dan ook burgers van die Republiek en $230(10 \%)$ is Afrikaanssprekend. Die res gebruik Engels as spreektaal.

\section{Bevolkingsverspreiding.}

Streeksgewys.

Wat digtheid per territoriale eenheid betref, het ons met 'n oneweredige distribusie te doen wat wissel van 300 tot 42 per vk. $\mathrm{m}$. In die middelveld is die gemiddelde digtheid ongeveer 60 per vk. m. en word $39 \%$ van die bevolking aangetref. In die laeveld, Lubomboplato en hoëveld is dit 27, 32 en 46 per vk. m. respektiewelik.

TABEL 2.*

Bevolkingsverspreiding (1962 - geskat) per geografiese streek.

\begin{tabular}{|c|c|c|c|c|c|c|c|c|c|}
\hline 范 & 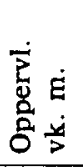 & 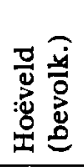 & 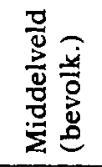 & 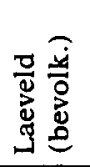 & 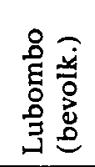 & 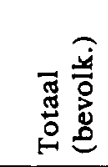 & 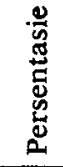 & 尔 & 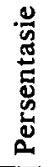 \\
\hline Hlatikulu & 1,870 & 16,200 & 41,800 & 21,000 & 300 & 79,300 & 28 & 64,300 & 35 \\
\hline Mankaiana & 900 & 30,700 & 6,300 & 200 & - & 37,200 & 13 & 25,700 & 15 \\
\hline Manzini & 1,000 & 1,700 & 39,400 & 12,300 & - & 53,400 & 19 & 26,500 & 14 \\
\hline Mbabane & 800 & 32,000 & 5,500 & - & - & 37,600 & 14 & 22,300 & 12 \\
\hline Piggs P. & 630 & 11,300 & 16,800 & 3,500 & - & 31,600 & 11 & 22,100 & 11 \\
\hline Stegi & 1,500 & - & 400 & 25,400 & 15,400 & 41,200 & 15 & 27,300 & 11 \\
\hline Swaziland & 6,700 & 92,000 & 110,200 & 62,400 & 15,700 & 250,300 & & 185,200 & \\
\hline Tot. vk. m. & 6,700 & 2,000 & 1,900 & 2,300 & 520 & & & & \\
\hline $\begin{array}{l}\text { Digtheid } \\
\text { p.vk. m. }\end{array}$ & 42 & 46 & 58 & 27 & 32 & 42 & & & \\
\hline $\begin{array}{l}\text { persentasie } \\
\text { v. bevolk. } \\
\text { (ongeveer }\end{array}$ & & 36 & 39 & 22 & 5 & & & & \\
\hline
\end{tabular}

* Gebaseer op Swaziland Report, 1962, bl. 9. 
Hoewel die middelveld nie na oppervlakte die grootste gebied is nie, dra dit vanweë die hoë bevolkingsdigtheid die grootste bevolking. Die laeveld is die grootste enkele streek met die laagste bevolkingsdigtheid en die tweede kleinste bevolkingsgetal. Met die uitbreiding van besproeiingsondernemings sal die drakrag van hierdie gebied onteenseglik sterk verhoog kan word.

Die distrikte Manzini, Stegi en Mbabane het sedert 1945 die grootste bevolkingsgroei beleef, t.w. 1700,1200 en 1000 p. j. respektiewelik. Alhoewel Hlatikulu die grootste distrik is wat oppervlakte sowel as bevolking betref, het sy aandeel aan die Swazilandse bevolking van $35 \%$ in 1946 gedaal tot $28 \%$ in 1962. Aangesien dit in werklikheid 'n toename van 15,000 toon moet die relatiewe afname eerder toegeskryf word aan die feit dat die ander distrikte se toename soveel groter was.

Ongeveer $70 \%$ van die bevolking $(196,000$ persone, almal Bantoes) is woonagtig in die Swazigebied, wat $52 \%$ van die landsoppervlakte beslaan. Die gebiede in private besit het die kleinste digtheid. Van die 35,000 bewoners van lg. gebied is 31,500 Bantoes (meestal plaasarbeiders en hulle afhanklikes), ongeveer 400 plaaseienaars met hulle gesinne en die res is plakkers.

\section{Stedelik-Plattelands.}

Vir 'n berekening van die bevolkingsverspreiding op 'n stedelik-plattelandse grondslag word die nuwere sentra wat om die ontwikkelingsprojekte ontstaan op grond van die arbeid en leefuyse as stedelik beskou.

TABEL 3.*

Stedelike en plattelandse bevolkingsverspreiding gebied.

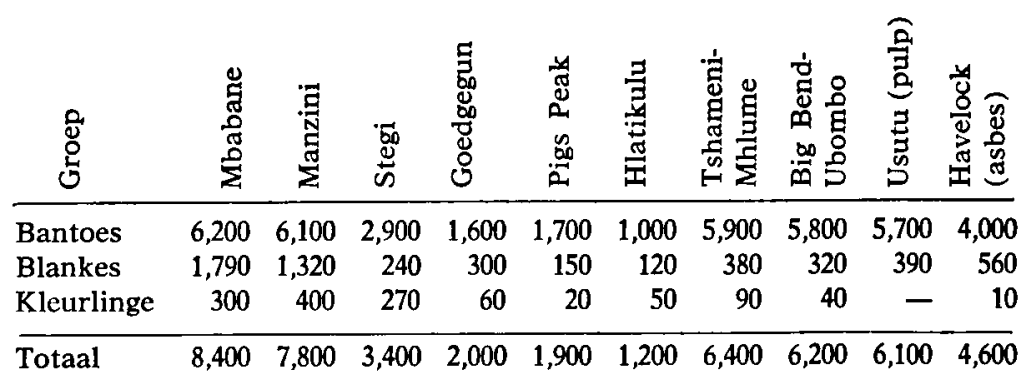

Opm.: Alle syfers is afgerond tot die naaste 10 of 100 .

* Gebaseer op Swaziland Report, 1962, bl. 16-17. 
Hierdie stederike bewoners maak slegs $17 \%$ van die totale Swazilandse bevolking uit. Ongeveer $15 \%$ van die Bantoes $(41,000)$ woon in stedelike sentra. Terwyl dit $13 \%$ van die Swazilandsgebore Bantoes verteenwoordig, sluit dit $36 \%$ van die Bantoes in wat van buite die gebied herkomstig is. Hieronder is die Mosambiekse Bantoes veral in groot getalle aanwesig. Die blankes is verreweg die meeste verstedelik, nl. 69\% (5,570), daarna volg die Kleurlinge ( $55 \%$ of 1,240 ). Ten gevolge van die groot oorwig van die Bantoebevolking $(96.3 \%)$ oor die blankes $(2.9 \%)$ en die Kleurlinge $(0.8 \%)$, d.w.s. 33 Bantoes teenoor elke blanke, is die inwonertal van die stedelike gebiede nogtans $85 \%$ Bantoes, $12 \%$ blankes en 3\% Kleurlinge. Aan die ander kant bestaan die plattelandse bevolking vir $99 \%$ uit Bantoes.

Dit sou enigsins onjuis wees om selfs die 41,000 Bantoes in die volle sin van die woord as verstedelik te bestempel. Die meerderheid is waarskynlik alleen in en nog nie (sosiologies gesproke) van die stedelike gebiede nie. 'n Latere paragraaf oor die arbeidsmigrasie werp interessante lig hierop. Op hierdie stadium hoef alleen daarop gewys te word dat van die 41,000 Bantoes slegs 9,600 vir langer as 10 jaar hulle verblyf in hierdie gebiede het. Dit verteenwoordig minder as 'n kwart (23\%) van die stedelike en minder as $4 \%$ van die totale Bantoebevolking. Verstedeliking is derhalwe ' $n$ betreklik nuwe verskynsel in die Swazilewe. Indien die 41,000 stedelike Bantoes nog weer verdeel word op grond van geboorteplek (vir sover as wat dit toegepas kan word op etniese affiniteit, d.w.s. Swazi- of nie-Swazi), mag die groep verstedelikte Swazi's nog minder blyk te wees.

Geslags- en leeftydsdistribusie.

Vroue is in die meerderheid in die bevolkingstotaal met 'n oorskot van ongeveer 9,500. In die leeftydsgroep bo 21 jaar is daar 53 vroue vir elke 47 mans en in die jonger groep (onder 21 jaar) 51 dogters vir elke 49 seuns. Hierdie verhoudinge is betreklik konstant sedert 1904 . Die verhouding by geboorte is 108 vroulik per 100 manlik. Die oorskot van 400 vroue onder een jaar neem toe tot 1300 jeugdiges en 7,800 volwassenes. Onder die blankes is die verhoudinge enigsins anders, nl. 54 manlikes vir 46 vroulikes vir sover dit volwassenes betref en 
52 tot 48 vir jeugdiges. Veertig jaar gelede was die verhouding selfs nog minder ewewigtig, nl. $56: 44$. Ook hierdie syfers dui op die immigrante- en tydelike verblyfsaard van 'n aansienlike deel van die blanke-bevolking.

Die voorgaande opmerking geld ook die stadsbevolking en dui op die feit dat dit 'n nuwe tendens is. Nieteenstaande die oorwig van vroulikes onder die Bantoebevolking is die stedelike bevolking oorwegend manlik, nl. $51: 49$ vir volwassenes, maar wat die jeugdiges betref is daar 48 seuns vir elke 52 dogters. Dit beklemtoon die feit dat dit die jeugdiges is wat na die stedelike sentra verskuif.

Aangesien geboorteregistrasie vir Bantoes nie verpligtend is nie, kan die getal geboortes allen geskat word. In 1946 is die geboortesyfer, d.w.s. oorlewendes na een jaar, bereken op 56 per 1000 van die bevolking. Daarna volg 'n aansienlike daling tot 37 per 1000 . Die sterftesyfer het ook 'n daling ondergaan, t.w. van 27 per 1000 in 1956 tot 22 per 1000 in 1962. Alhoewel sodanige berekening van geboorte- en sterftesyfer te algemeen is om besondere konklusies te kan trek, is dit tog interessant om dit te vergelyk met die geboorte- en sterftesyfer vir blankes in dieselfde gebied, nl. 18 en 7 per 1000 respektiewelik.

\section{Sosio-ekonomiese aspekte.}

Geletterdheid.

Ongeveer 69,200 persone bo 9 jaar (36\% van hierdie leeftydsgroep) is in staat om ten minste een taal te lees en te skryf. Onder blankes en Kleurlinge is hierdie vaardigheid feitlik algemeen. Wat die Bantoes betref is daar beslis ' $n$ toename in omvang sowel as in kwaliteit waarskynlik. Van die stedelike Bantoes oor 9 jaar kan $65 \%$ lees en skryf, teenoor $28 \%$ in plattelandse gebiede. Die aantal Bantoes wat kan lees en skryf het aangegroei van ongeveer 48,000 in 1956 tot 61,700 in 1962.

Die mate van onderwys wat die bevolking ontvang het, blyk uit die volgende tabel. 
TABEL $4 .^{*}$

Onderwysstandaard.

\begin{tabular}{|c|c|c|c|c|c|c|}
\hline $\begin{array}{r}8 \\
\text { ơ } \\
\end{array}$ & 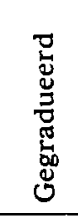 & 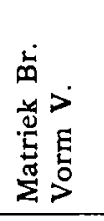 & 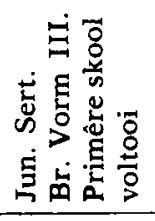 & & & 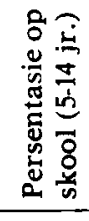 \\
\hline Bantoes & 60 & 400 & 1,650 & 4,250 & ) & \\
\hline Blankes & 380 & 1,960 & 3,290 & 9,380 & ) & $57 \%$ \\
\hline Kleurlinge & 10 & 50 & 180 & 570 & ) & \\
\hline
\end{tabular}

* Gebaseer op Swaziland Report 1962, bl. 14.

Onderwysgeriewe.

Onderwys word voorsien deur 'n selfstandige departement met hoofkantoor in Mbabane. Dit is verantwoordelik vir alle onderwys tot aan die einde van die sekondêre skool, insluitende tegniese opleiding. Die gebruik wat van die skole gemaak word, blyk uit die inskrywing van leerlinge.

\section{TABEL $5^{* \star}$}

Inskrywings by verskillende tipes skole (1962).

\begin{tabular}{|c|c|c|c|c|c|c|}
\hline 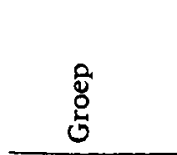 & 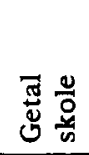 & 怘 & 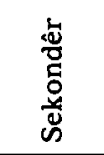 & 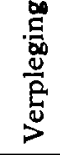 & 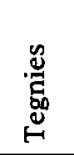 & 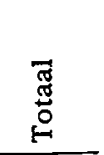 \\
\hline Bantoes & 292 & 39,263 & 1,999 & 76 & 201 & 43,463 \\
\hline Blankes & 12 & 1,128 & 427 & - & - & 1,555 \\
\hline Kleurlinge & 5 & 640 & 89 & - & - & 729 \\
\hline Tota: & 309 & 41,031 & 2,515 & 76 & 201 & 45,747 \\
\hline
\end{tabular}

** Gebaseer op Swaziland Report 1962, bl. 57.

Een van die opmerklike verskynsels in hierdie tabel is die groot verskil tussen die leerlinggetalle van die primêre en die sekondêre skole, veral ook met betrekking tot die ver- 
skillende groepe. Minder as 5\% van die Bantoeleerlinge van die primêre skool bereik die sekondêre afdeling; meer as $24 \%$ van die blankes en byna $11 \%$ van die Kleurlinge. Die indruk bestaan ook dat die minder as $25 \%$ oorgang by die blankes kunsmatig laag gehou word deurdat hulle kinders na die primêre skool na sekondêre skole buite Swaziland gestuur word. Dit geld nié die Bantoes en Kleurlinge nie.

\section{Beheer en beleid.}

Die Swaziland Public Education Proclamation No. 31 van 1943 maak voorsiening vir die verkiesing van skoolkomitees vir enige openbare blankeskool in die gebied. Die lede is ouers met skoolgaande kinders en die Distrikskommissaris is voorsitter. Die komitees het 'n adviserende funksie, hoewel die departement uitvoerende magte en pligte aan hulle kan opdra.

Soos uit die vorige en volgende paragrawe sal blyk, was die beleid tot onlangs afsonderlike skole vir die kinders van die onderskeie rassegroepe. Hiervan is sedert 1962 op 'n betreklik versigtige maar eweneens duidelike wyse afgesien. Ooreenkomstig die African Schools Proclamation No. 6 van 1940 het Regeringskennisgewing no. 52/1954 voorsiening gemaak vir die daarstelling van adviserende onderwyskomitees op 'n distriksbasis. In 1962 is daar vir die eerste keer 'n interrassiese Adviserende Onderwysraad in die lewe geroep ter vervanging van die drie afsonderlike Adviserende Rade wat hulle tot op daardie datum besig gehou het met die onderwysbelange van die drie rassegroepe. Die nuwe beleid van rasse-integrasie in die skole word tot uitdrukking gebring in die volgende besluit wat deur die Regering aanvaar en van 1963 af in werking gestel is: „Subject to accommodation being available Coloured or African pupils may be admitted to the Grade 1 class of European schools, on a day-scholar basis, provided that (i) the applicant's age does not exceed 7 years at 1st January 1963; (ii) the headmaster is satisfied that the applicant has sufficient command of English to enable him/her to follow the teaching and (iii) the headmaster is satisfied that the child is in a position to observe all the school rules".

Alhoewel dit ' $n$ duidelike verandering is na 'n integrasiebeleid, is die benadering nogtans versigtig. Skooldeure word nie meteens oopgegooi vir alle Bantoeleerlinge nie. Beskikbare akkommodasie, leeftyd, taalbeheer en huislike agtergrond is 
faktore wat 'n stremmende invloed sal uitoefen, hoewel dit geen absolute werende gevolg sal hê nie. Dit was in 1963 egter reeds duidelik dat die reëling baie blankes nie aangestaan het nie en dat hulle liewer hulle kinders na skole elders gestuur het. Die regering van die Republiek het aan sy onderdane besondere tegemoetkoming in hierdie verband verleen.

\section{Bantoeskole.}

Soos aanvanklik in Suid-Afrika en elders op die vasteland, het private ondernemings, veral die sending, ook in Swaziland 'n prominente, selfs oorheersende aandeel gehad in die voorsiening en beheer van skole vir die inheemse bevolking. Die meeste Bantoeskole in Swaziland tesame met 'n huishoudskool, 'n opleidingsentrum vir verpleegsters en 'n onderwysersopleidingskool word op hierdie wyse beheer, hoewel met staatsteun. Regeringsbeleid was altyd sterk ten gunste van hierdie patroon. Desnieteenstaande word ongeveer 'n twintigtal skole deur die staat onderhou. Dan is daar die drie sg. National Schools wat deur die Swazilandse Tesourie onderhou word teen 'n koste van $\mathrm{R} 60,000$ per jaar. Verder word stamskole ingestel deur plaaslike gemeenskappe onder leiding van hoofmanne. Sommige hiervan ontvang geldelike ondersteuning van die regering of van die Swazi se Nasionale Tesourie. Benewens kerklik ingestelde en beheerde skole is derhalwe ook beweeg in die rigting van Staatskole en nasionale en/of stamskole vir die Swazi's. Die neiging is egter nie so konsekwent en logies deurgevoer soos in die Republiek nie.

Drie hoërskole lei op tot die Suid-Afrikaanse matriekstandaard; 25 bied junior sekondêre opleiding aan vir die High Commission's Territories' Junior Certificate; 65 is volle primêre skole met opleiding tot st. VI ( $8 \mathrm{jr}$.), en die res lei op tot st. IV ( $6 \mathrm{jr}$.) of slegs tot st. II ( $4 \mathrm{jr}$.).

The Mbabane is 'n regeringsbeheerde ambagskool wat opleiding verskaf in bouwerk, skrynwerk, motorwerktuigkunde en die installering van elektriese toerusting. In 1962 was daar 75 ingeskrewe vakleerlinge as kosgangers by dié skool ingeskryf. Verdere ambags- en beroepsopleiding word verskaf deur 'n huishoudskool en die Ainsworth Dickson Nursing School. Soos die name aandui word hier alleenlik meisies opgeneem vir huishoudkunde en verpleging respektiewelik.

Daar is twee opleidingskole vir onderwysers. Albei bied 
tweeledige professionele kursusse aan, t.w. die Primary Lower ( 2 jaar na st. VII) en 'n Primary Higher ( 2 jr. na st. VIII). Dat die onderwysersopleiding dus nog maar op lae vlak staan, behoef geen betoog nie. Personeel met 'n hoër opleiding, soos dié van die nuwe Swaziland Teacher Training College te Manzini (geopen in 1962) het hulle opleiding buite Swaziland gehad, meestal in die Republiek.

Aan die Swaziland Teachers Training College is ook 'n klerklike opleidingsentrum verbonde. Dit verskaf 'n tweejarige kursus na Junior Sertifikaat.

TABEL 6.*

Inskrywings van Bantoeleerlinge volgens soorte skole.

\begin{tabular}{|c|c|c|c|c|c|c|c|c|c|c|c|c|}
\hline \multirow[t]{2}{*}{ Skole } & \multicolumn{5}{|c|}{ Onderwys } & \multicolumn{6}{|c|}{ Kinders } & \multirow[b]{2}{*}{ 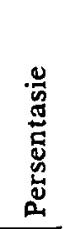 } \\
\hline & 芯 & 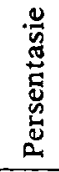 & $\underset{⿱ 乛 龰}{0}$ & 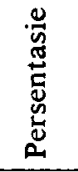 & 怘 & 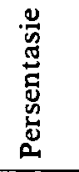 & 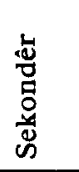 & 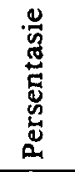 & 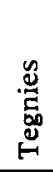 & 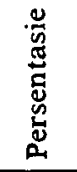 & 夛 & \\
\hline Staat & 20 & 6.8 & 164 & 13.3 & 5,152 & 13.2 & 564 & 28.3 & 118 & 58.7 & 5,838 & 14.1 \\
\hline Staatsond. & 129 & 43.8 & 825 & 66.9 & 25,168 & 63.7 & 1,250 & 62.6 & 83 & 41.3 & 26,501 & 63.5 \\
\hline Nasionaal & 3 & 1.0 & 34 & 2.8 & 868 & 2.3 & 181 & 9.1 & 一 & - & 1,049 & \\
\hline Stam & 39 & 13.4 & 60 & 4.9 & 2,272 & 5.9 & - & - & - & 一 & 2,272 & \\
\hline Privaat & 104 & 35.3 & 149 & 12.1 & 5,803 & 14.9 & - & - & 一 & - & 5,803 & 14 \\
\hline Totaal & 295 & 100 & 1,232 & 100 & 39,263 & 100 & 1,999 & 100 & 201 & 100 & 41,463 & 100 \\
\hline
\end{tabular}

* Gebaseer op Swaziland Report, 1962, bl. 61.

Uit die gegewens van hierdie tabel blyk dit:

(i) Die staatskole is in getalle op een ná die kleinste groep. Dit vorm $6.8 \%$ van die getal skole maar dit het $13.3 \%$ van die onderwysers en $14.1 \%$ van die skoliere. Dit het verder $13.2 \%$ van alle primêre, $28.3 \%$ van alle sekondêre en $58.7 \%$ van alle leerlinge in tegniese skole;

(ii) die staatsondersteunde skole is die meeste (129 of $43.8 \%$ ); $66.9 \%$ van die onderwysers en $63.9 \%$ van die leerlinge is hieraan verbonde. In die primêre afdeling het dit $63.7 \%$, in die sekondêre afdeling $62.6 \%$ en in die tegniese afdelings 41.3\% van die getal leerlinge vir die betrokke afdelings. Die verhouding skole, onderwysers, primêre en sekondêre leerlinge is in hierdie geval betreklik eweredig; 
(iii) die drie skole wat deur die Swazi National Treasury onderhou word, is $1 \%$ van die skole, maar dit het $2.8 \%$ van die onderwysers en $2.5 \%$ van die leerlinge. Ook hier staan leerlinge en onderwysers in betreklike ewewig, hoewel opgemerk moet word dat dit $2.3 \%$ van die primêre maar $9.1 \%$ van die sekondêre leerlinge huisves;

(iv) hoewel die 39 stamskole $13.4 \%$ van die skole vorm, het hulle slegs $4.9 \%$ van die onderwysers en $5.5 \%$ van alle leerlinge $(5.9 \%$ van die primêre leerlinge). Dit moet betreklik klein skooltjies wees;

(v) die tweede grootste aantal skole behoort tot die klas private skole: 104 skole en $35.3 \%$. Maar hulle het slegs $12.1 \%$ van die onderwysers en $14.0 \%$ van die leerlinge. Dit is derhalwe ook oorwegend klein.

\section{Blankeskole.}

Vir blankes was daar in 196212 skole, waarvan elf deur die staat en een deur 'n Rooms-Katolieke orde onderhou is. Twee hiervan, nl. St. Marks te Mbabane en Evelyn Baring te Goedgegun, lei op tot die Suid-Afrikaanse matriekstandaard. Albei is kosskole. Die Dominican Convent is 'n meisieskool wat ook enkele sekondêre kursusse aanbied.

\section{Kleurlingskole.}

Vir Kleurlinge is daar 5 skole, wat almal deur private liggame beheer en onderhou word, alhoewel met staatsubsidie. Drie hiervan gee opleiding tot Junior Sertifikaat en die res is suiwer primêre skole.

\section{Onderrig aan volwassenes.}

Die onderwysdepartement probeer om in hierdie behoefte, wat uiteraard veral die Bantoebevolking tref, te voorsien deur biblioteek- en filmdienste. Onder vroue word veral gewerk deur middel van allerlei klubs wat oor die hele gebied versprei is. Kursusse in lees en skryf vir volwassenes word deur private ondernemings in verskeie sentra aangebied. Sodanige geletterdheidskursusse word ook aan gevangenes gegee en staatsamptenare wat dit verkies, word onderrig in Siswati. 


\section{Hoër onderwys.}

Die gebied beskik oor geen universiteit nie. 'n Beperkte aantal studente (41 in 1962) besoek universitêre inrigtings in Basoetoland, die R.S.A. en die Verenigde Koninkryk met behulp van regeringsbeurse, lenings e.d.m.

\section{Finansiering.}

Van 1962 af is blanke leerlinge verplig om te betaal vir handboeke en skryfbehoeftes. Die lopende kapitaal wat op hierdie wyse gespaar word, is oorgedra na Bantoe- en Kleurlingskole vir toerusting en hulpmiddels. Voor 1962 het blankes nie hiervoor betaal nie; Bantoes het 'n klein bedraggie betaal terwyl in ooreenstemming met 'n ou wet, Kleurlingkinders 'n klein subsidie vir uitgawes aan boeke en skryfbehoeftes verbonde ontvang het. Uit die Colonial Welfare and Development Fund is R200,000 bygedra vir die bou van die onderwyserskollege. 'n Beeld van die onderwysuitgawes word uit die volgende tabel verkry:

TABEL 7.*

Onderwysuitgawes.

\begin{tabular}{llrrr} 
Groepe & $\begin{array}{c}\text { Soort } \\
\text { Uitgawe }\end{array}$ & $\begin{array}{c}1960 \\
\text { Rand }\end{array}$ & $\begin{array}{c}1961 \\
\text { Rand }\end{array}$ & $\begin{array}{r}1962 \\
\text { Rand }\end{array}$ \\
\hline Bantoe & Lopende & 367,860 & 468,712 & 498,398 \\
& Kapitale & 85,722 & 318,848 & 280,332 \\
Blank & Lopende & 241,552 & 197,234 & 340,160 \\
& Kapitale & 60,360 & 173,246 & 41,444 \\
Kleurling & Lopende & 35,220 & 35,112 & 29,404 \\
& Kapitale & - & 28,352 & 35,820
\end{tabular}

Oor die drie jare was daar 'n konstante styging in lopende uitgawes vir Bantoeonderwys, wat seker 'n aanduiding is van die toenemende uitbreiding hiervan. Met 'n daling in 1961 was daar nog 'n styging in lopende uitgawes vir blankeskole, maar. 'n konstante daling wat lopende uitgawes verbonde aan Kleurlingskole betref. Wat kapitale uitgawes betref, blyk dit ook

* Verwerk uit Swaziland Report 1962, bl. 59. 
duidelik dat Bantoeonderwys besondere aanspraak op die tesourie gemaak het. Die uitgawes aan blankeskole toon waarskynlik die meer gevestigde aard van hierdie skole. Kleurlingskole het van 1961 af 'n aansienlike bedrag vir kapitale uitgawes ontvang. Dit mag dui op 'n vroeëre agterstand op hierdie gebied.

'n Vergelyking van lopende uitgawes in 1962 op grond van leerlinggetalle, bring ' $n$ interessante toestand aan die lig. Die Bantoeleerlinge, $95 \%$ van die leerlingtal, ontvang $57.4 \%$ van die lopende uitgawes; aan die blankeleerlinge, $3.4 \%$ van die totaal, word $39.2 \%$ van die lopende uitgawe bestee terwyl die Kleurlinge ( $1.6 \%$ van die leerlingtal) $3.4 \%$ van die lopende uitgawes ontvang. Dit geld natuurlik alleen staatsuitgawes, want veral aan Bantoeleerlinge word ook uit private bronne heeluat bestee.

\section{Landbouonderwys.}

Waar $85 \%$ van die Bantoebevolking nog op die platteland woon en derhalwe uit die boerdery 'n bestaan maak, is dit vanselfsprekend dat landboukundige opleiding van besondere betekenis is. Daar is twee landbou-opleidingsentra, nl. te Mdutshane en Mpisi, wat elementêre opleiding verskaf aan landbouvoorligters en wagters vir die veeartsenykundige dienste. Planne is opgestel vir 'n landboukollege en 'n sentrum vir kort kursusse ten einde opleiding aan te bied vir erkende diplomastandaarde en om voorsiening te maak vir korttermynopleiding vir progressiewe boere, hoofmanne, onderwysers en indiensopleiding van personeel. Die kapitaal hiervoor word verskaf deur die Freedom From Hunger Campaign, asook die lopende kapitaal vir die eerste drie jaar ( 270,000 ).

Aansienlike aandag word geskenk aan bevordering van boerderykennis onder Swaziboere. Veral die Land Utilization Department is hiermee bedrywig. Deur besoeke aan naburige gebiede, konferensies, toere en indiensopleiding is nuwe voorligtingstegnieke gedurende 1962 bevorder. 'n Geskenk van Oxfam (Oxford Committee for Famine Relief), nl. 'n Landrover toegerus met films en skyfies, luidsprekers en bandopnemers het grootliks bygedra tot verspreiding van boerderykennis.

Van die 122 Swazi Farmers' Associations met 'n ledetal van ongeveer 4000 word goeie gebruik gemaak vir die genoemde 
doel. Vir die doel word verder gebruik gemaak van 114 demonstrasiepersele. 'n Spesiaale landbouweek vir skole is ook gehou na 'n voorafgaande kort kursus vir onderwysers. Gedurende die week is 6500 kinders by 91 skole deur personeellede van die Landbou- en Onderwysdepartement en van die Distriksad ministrasie toegespreek. Landbouskoue, die Master Farmer Scheme (1965) en enkele vroueverenigings dien ook as voorligtingskanaal.

\section{Arbeidsaangeleenthede.}

Indiensneming.

Volgens die 1956-sensus was slegs $25 \%$ van die blankes bo 15 jaar wat in loonarbeid bedrywig was, betrokke by die landbou en bosbou; $20 \%$ is aangegee as ambagslui en arbeiders, $18 \%$ as beroepslui (onderwysers, ingenieurs, sendelinge, regspraktisyns en medici) terwyl $11 \%$ administrateurs en bestuurders was. Vir die Kleurlinge was die indeling soos volg: landbou en bosbou: $30 \%$ en ambagte en arbeid: $26 \%$.

Van die Swazi's was 25,928 kleinboere, 200 selfgeëmplojeerde sakelui en 26,050 arbeiders waarvan net meer as die helfte $(14,322)$ binne die gebied in diens was. Aan die ander kant is 3,470 vreemde Bantoes binne Swaziland geëmplojeer.

Uit die totale arbeidsmag was $24 \%$ betrokke by die boerdery en bosbou (dit sluit uiteraard nie kleinboere in nie), $9 \%$ by huisdiens en $29 \%$ by die mynbedryf. Van die 7,619 mynarbeiders kom $87 \%$ van buite die gebied. Die verskynsel word verklaar deur die populêre bewering deur werkgewers in Swaziland dat hulle Sjangaans as werkers verkies bo Swazi's. Lg. word beskou as minder konstante, minder bevoeglike en gedienstige werkers wat ook makliker terugval op hulle tradisionele landboubestaan.

Op grond van die sosiale opname van 1960 is die volgende beeld verkry van die werkende Bantoebevolking tussen 15 en 64 jaar. (Vgl. Swaziland Report 1962, bl. 19).

Totaal: 138,000 d.w.s. $51 \%$ van die Bantoebevolking.

Manlik: $\quad 65,800$

Vroulik: $\quad 72,100$ 
In diens:

Totaal: $\quad 38,000$

Manlik: $\quad 32,000$ d.w.s. $49 \%$ van die mans.

Vroulik: $\quad 5,700$ d.w.s. $8 \%$ van die vroue.

Plattelands $\quad 24,800$

Stedelik $\quad 5,400$

Industriële

Nedersettings $\quad \mathbf{8 , 0 0 0}$

Die verskil tussen diegene van werkende leeftyd en dié werklik in diens, is 99,800. Daarvan was 20,000 leerlinge. Daar bly dan nog meer as 80,000 persone, 22,300 mans en 57,000 vroue sonder betrekking of opleiding. Sommige hiervan is selfgeëmplojeer, t.w. handelaars en kleinboere (in 1956 was byna 26,000 kleinboere), baie is huisvroue en die res bestaan hoofsaaklik uit persone wat rus tussen hulle tydperke van trekarbeid. Die gemiddelde Suaziman bestee $40 \%$ van sy tyd aan loonarbeid, d.w.s. 2 jaar uit 'n siklus van 5 jaar. Daar bly 'n duidelike onderindiensneming van hierdie landelike groep, wat 'n aansienlike reserwe aan arbeidskragte verteenwoordig.

Die indiensneming van Bantoewerkers in plattelandse en stedelike gebiede vergelyk soos volg:*

Plattelandse

Stedelike

persentasie persentasie

\begin{tabular}{lcccc}
\hline & Mans & Vroue & Mans & Vroue \\
\hline In loondiens & 40 & 5 & 70 & 21 \\
Tans nie in diens & & & & \\
maar voorheen wel & 45 & 3 & 21 & - \\
Nooit in diens & 15 & - & 9 & -
\end{tabular}

Die indiensnemingsyfer is deurgaans hoër in die stedelike gebiede as in die plattelandse. Die groot persentasie rustendes en wat nog nie in loondiens was nie val veral op in lg. gebied. Die plattelandse tuiste is nog die rusplek vir die werker uit dié gebied: Die stad is vir hom nog geen tuiste nie maar alleen 'n plek wat geleentheid bied om deur tydelike verblyf kontant te verdien en ervaring op te doen.

* Gebaseer op Swaziland Report 1962, bl. 20. 
In 1960 is die volgende loonarbeiders in die volgende nywerheidsklasse verdeel:*

$\begin{array}{cr}\begin{array}{c}\text { Persentasie van } \\ \text { landelikes }\end{array} & \begin{array}{r}\text { Persentasie } \\ \text { Stedelikes }\end{array}\end{array}$

\begin{tabular}{|c|c|c|c|c|c|c|}
\hline & 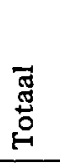 & 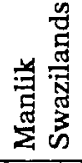 & 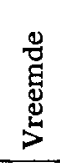 & 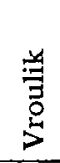 & 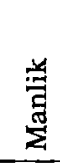 & $\frac{7}{3}$ \\
\hline Landbou en bosbou & 36 & 52 & - & 22 & - & - \\
\hline Myne & 31 & - & 65 & - & - & - \\
\hline Regeringsdiens & 9 & 14 & - & - & - & - \\
\hline Handel & - & - & - & - & 38 & 18 \\
\hline Huisdiens & - & - & - & 61 & - & 65 \\
\hline Godsdiens en welsyn & - & - & - & 11 & - & - \\
\hline
\end{tabular}

Hierdie gegewens laat blyk weer eens watter groot per sentasie mynwerkers en werkers in regeringsdiens nie Swazi's is nie.

Verder blyk dit dat die meeste Swazi's nog betrokke is by ongeskoolde handearbeid, nl. $80 \%$ van die platteland en $40 \%$ van die stedelike mans (1960). Die beroepsverdeling volgens platteland-stedelike onderskeiding sien daar soos volg uit:

\begin{tabular}{lcccc} 
& \multicolumn{2}{c}{ Plattelands } & \multicolumn{2}{c}{ Stedelik } \\
& Mans & Vroue & Mans & Vroue \\
\hline Klerklik & $3 \%$ & $-\%$ & $16 \%$ & $-\%$ \\
Professioneel & 4 & 14 & 13 & 22 \\
Dienste & 7 & 61 & 10 & 66 \\
Ambagte & 2 & - & 9 & - \\
Verkoopslui & 4 & 13 & - & 3 \\
Handearbeid & 80 & 10 & 40 & 5 \\
Ander & - & 2 & 12 & 4 \\
\hline & 100.00 & 100.00 & 100.00 & 100.00
\end{tabular}

Dit is duidelik dat die stedelike gebiede nie alleen meer geleenthede vir klerklike en professionele persone en mense

* Gebaseer op Swaziland Report 1962, bl. 20. 
betrokke by die dienste en die ambagte, wat sosiaal en ekonomies hoër gewaardeer word, bied nie maar dan ook meer sulke mense trek.

Die volgende ontleding van werkers betrokke by industriële ondernemings met meer as 50 werkers in diens toon enersyds die indiensneming in die verskillende bedrywe en andersyds die verteenwoordiging van Swazilandse en vreemd: werkers.*

Indiesneming Vreemde arbeiders

\begin{tabular}{lrrrr}
\hline Bedrywe & 1961 & 1962 & 1961 & 1962 \\
Myne & 1,552 & 1,361 & 816 & 618 \\
Bosbou en bosbouprosesse & 5,047 & 4,675 & 431 & 372 \\
Landbou-ondernemings & & & & \\
(suiker en suikerverw.) & 7,623 & 7,634 & 2,126 & 2,074 \\
Konstruksie & 463 & 2,469 & 79 & 462 \\
Staatsdepartemente & 2,124 & 1,964 & 108 & 78 \\
Diverse vervaardiging & 158 & 126 & 3 & 9 \\
Ander & 82 & 245 & 7 & 14 \\
\hline Totale & 17,049 & 18,474 & 3,570 & 3,667
\end{tabular}

Die volgende opmerkings is ter sake: Daar is feitlik deurgaans 'n afname in indiensnemingsyfers van 1961 na 1962. Die enigste uitsondering is by konstruksie, wat klaarblyklik verband hou met die spoorwegaanleg, padbou e.d.m. Die aantal vreemde naturelle is min of meer konstant oor die twee jaar en is veral sterk verteenwoordig in die myn-, bosbou- en landboubedrywe.

Arbeidsmigrasie.

Daar is reeds verwys na die "rustende" werkers en die feit dat 'n Swaziman gemiddeld twee uit elke vyf jaar sy arbeid verkoop. Meer as $43 \%$ van die plattelandse manlike werkende bevolking wat in 1960 buite die gebied werksaam en $7 \%$ man. likes uit die dorpe; vir vroue was die syfers $36 \%$ en $1 \%$ respektiewelik. In 1962 was 9,400 mans en 500 vroue werksaam in die R.S.A. Die myne was verreweg die grootste werkgewers. In 1961 was daar 5,500 Swazimans werksaam op die Witwatersrandse goudmyne en 450 in die Natalse steenkoolmyne. In 1962 was dit 8500 en 400 onderskeidelik.

* Gebaseer op Swaziland Report 1962, bl. 20. 
Rekrutering word streng beheer deur die African Labour Proclamation. Werkkontrakte is beperk tot 'n termyn van een jaar maar duur meestal slegs 3 tot 9 maande. Die orige aantal werksoekendes buite Swaziland (2500-3000) tree op op eie inisiatief en word in diens geneem as plaasarbeiders of as mynwerkers in die aangrensende distrikte van die R.S.A.

\section{B. ETNOGRAFIES}

Herkoms.

Die Swazi's is die noordelikste deel van die Nguni-groep van die Suid-Afrikaanse Bantoes. Hulle is ten nouste verwant aan hulle suidelike bure, die Natalse Nguni, beter bekend as die Zoeloes. Die Swazitaal en -kultuur sluit ten nouste by dié van Zoeloes aan hoewel fisieke, kulturele en taalvermenginng met die Sotho en tot 'n geringe mate met die Tsonga, sigbaar is. Van die 70 sibbes dra $70 \%$ Nguni, 25\% Sotho- en 5\% Tsonganame.

Soos die Zoeloes was die Swazi's aanvanklik losse, hoewel kultureel en andersins verwante sibbes. Die vereniging tot volk dateer eintlik eers uit die vroeë jare van die 18e eeu. Die naam is afkomstig van die blankes wat die naam van die eertydse heerser, Mswati op sy volk oorgedra het. Die Swazi's self verkies om hulle baNtu bakaNguane, mense van Ngwane, te noem.

Die huidige koninklike sibbe, t.w. Nkosi Dlamini, het uit die noorde (embo) beweeg in die 15e eeu en hulle tydelik gevestig in suidelike Tongoland. Ongeveer 1770, lei Ngwane III sy volgelinge oor die Lubomboberge, tot aan die noordelike oewer van die Pongola. Uiteindelik bou hy sy hoofstad Lobamba in die huidige suid-oostelike Swaziland tussen die Pongolaen die Groot Usuturivier.

Uit hierdie sentrum het Ngwane, sy seun en kleinseun, Ndungunya en Sobhuza I die omliggende stamme onder hulle beheer gekry. 'n Botsing met die Ndwandwe van Zoeloeland het Sobhuza I en sy mense verplig om noordwaarts te verskuif tot naby die huidige Manzini, waar hulle die abeSuthu en enkele Nguni-sibbes aantref. Deur vrywillige onderwerping of as gevolg van gewelddadige oorrompeling is hulle ook almal onder gesag van die Dlamini gebring.

Sobhuza was 'n strateeg en staatsman. Om hom teen sy suidelike bure veilig te stel, trou hy met die dogter van Zwide, 
die Ndwandwe-hoof, en aan Shaka stuur hy twee van sy prinsesse. Aan die rebellevlugteling Soshangana uit die land van Shaka, verleen hy vreedsame deurgang deur sy gebied. Hy laat by sy dood aan sy seun 'n gevestigde ryk na met etlike duisende onderdane van verskillende herkoms en kultuur maar tog verenig deur een gesag en gevrees deur die naburige Bantoes.

Mswati was die vegter-koning. Soos Shaka reorganiseer hy sy leër tot 'n vaste, nasionale onderneming wat uit gevestigde militêre krale die bure, veral die Transvaalse of NoordSotho, beroof van vee en manskappe en tot diep in SuidRhodesië indring. Met die assimilasie van gevangenes en vlugtelinge word ' $n$ derde byvoeging tot die samestelling van die Swazivolk gemaak. Saamleef en ondertrouing sou die eenwordingsproses voltooi.

\section{Nedersettingspatroon.}

Soos by die Zoeloes en ander Nguni is die stat (umuti) die wooneenheid. Klein statte lê versprei oor die landskap, almal binne loopafstand van water, lande en veivelde. Een umuti word bewoon deur die kraalhoof (umnumzana) met sy moeder, vrou of vroue, sy ongetroude kinders, sy getroude seuns met hulle gesinne en woonlik ook ' $\mathrm{n}$ aantal ander afhanklikes. Na die dood van die kraalhoof, na 'n epidemie, by rusie met die bure of verskil met die stamhoof is die stat gewoonlik verskuif. Vandag laat gebrek aan voldoende grond en duursamer bouwyses sodanige verskuiwing nie meer toe nie.

Alhoewel nie so kompleks as die Zoeloestat nie, word die basiese aanlegpatroon van die Nguni tog hier gevolg. Die sirkelvormige isabaya (beeskraal) vorm die sentrum. Waar die ligging dit enigsins toelaat is die ingang aan die oostekant, d.w.s. sonop. Agter die kraal, d.w.s. aan die westekant, lê die woonhutte in ' $n$ boog of perdeskoenvorm met die indlunkulu of groothut min of meer reg agter die kraal. Selfs vandag, waar die krale neig om kleiner te word en die algemene patroon disintegreer, word hierdie orde blykbaar nog oorwegend aangetref. Die indlunkulu herberg die belangrikste vrou in die stat, t.w. die kraalhoof se moeder of, na haar dood, 'n plaasvervangster, gewoonlik uit haar familie. Daarin verskil die Swazi se indlunkulu van dié van die Zoeloe, wat die hoofvrou van die kraalhoof herberg. Waar die drieledige Zoeloe-indeling 
van die kraal by die Swazi ontbreek, vind ons hier 'n ver. spreiding van die hutte en komplekse (slaap-, kook- en berghutte) aan weerskante van die indlunkulu. Vir opgroeiende dogters is daar afsonderlike slaaphutte in hulle moeders se afdelings terwyl seuns en ongetroude mans in hutte op die punte van die boog slaap.

Alhoewel die koninklike kraal basies dieselfde patroon volg, is dit uiteraard groter en ingewikkelder. Solank hy minderjarig is, woon die opperhoof saam met sy moeder, maar in 'n ander afdeling. Na sy huwelik rig hy sy eie lilauu (woonplek vir mans) op op 'n afstand van dié van sy moeder. Enkele van sy minder belangrike vroue, sommige van sy regimente en van sy onderdane volg hom hierheen. Die koninginmoeder, die belangrikste vroue en voorwerpe vir nasionale seremonies bly in die hoofkraal.

Die Swazihut is die bekende byekorfvormige struktuur van die Nguni, bestaande uit 'n raamwerk van buigbare latte met 'n grasdekking. Die deur is laag en die vloer bestaan uit gestampte klei. Agterin is die umsamo, 'n semi-sirkel aangedui deur 'n kleirif op die vloer. Op die umsamo van die indlunkulu word die offerandes van bier, vleis en tabak vir die voorouergeeste gebring. In ander hutte word die umsamo nie gebruik nie. Die regterkant van die hut, bereken van die ingang af, behoort aan die man, die linkerkant aan die vrou.

Die sosiale struktuur berus basies op bloedverwantskap. Die kleinste eenheid is die gesin. Daarop volg die grotere verwantskaps- of familiegroepe en linies wat altyd volgens die vaderlike lyn bereken word tot by die hiërargiese, eksogame, maar lankal nie meer territoriale sibbes. Sommige hiervan toon 'n soort totemistiese verband met diersoorte. Hierin moet waarskynlik aanduidings van Sotho-invloede gesien word. Alleen die koninklike sibbe, Nkosi Dlamini, wyk af van die eksogame reël. Ter wille van huwelike binne die aristokratiese linies vind hier doelbewuste splitsing plaas. Die sibbes word verenig in stamme, wat op hulle beurt weer volgens kultuur en afkoms die Swazivolk en op grond van politieke eenheid die Swazinasie uitmaak.

Leeftyd speel ' $n$ uiters belangrike rol in die indiwiduele en nasionale lewe. Ouderdom is 'n teken van gesag. Die menslike lewensloop word in 'n aantal stadia verdeel. Eers is daar die babatydperk tot op 3 maande. Dit word afgesluit met die seremonie waar die kind aan die vader en die maan voorge- 
stel word. Vir die eerste keer is dit 'n persoon en nie meer 'n ding nie. Die kleutertydperk wat hiermee begin, duur totdat speentyd op ongeveer driejarige leeftyd aanbreek en hy al sy tande het. Van nou af word seksverskille ook beklemtoon. Die kinderstadium duur tot by die seremonie van oordeurboring. Die volgende stap word bereik met die individuele inisiasie. Dan volg die huwelik, wat vir dogters gouer aanbreek as vir mans. Die man bereik sy hoogste status met die aanbring van die hoofring. Die dood lei 'n nuwe fase in en die ukubayisa, die terugbring van die gees van die oorledene as 'n voorouergees, beëindig die proses.

Behalwe die beklemtoning van leeftyd in die persoonlike lewe, word daar ook elke 5 tot 7 jaar 'n leeftydsklas gevorm. Elkeen dra sy eie naam, besit sy eie onderskeidingstekens, liedere, barakke en ampsdraers. Dit vorm die basis van die volkswye regimente wat afgesien van militêre diens ook ander nasionale pligte gehad het en kultureel belangrik was as kweekplek van die tradisionele waardes.

Grond word deur die opperhoof gehou namens die volk Hy uys dit toe deur sy amptenare aan die stamhoofde en hulle weer aan die onderskeie families deur hulle hoofmanne. Vreemdelinge moet deur die opperhoof verlof verleen word $\mathrm{Dm}$ in die land te woon. Die vroue bewerk die grond wat deur hulle mans aan hulle toegesê is. Die belangrikste landbouimplemente was die graafstok en skoffelpik. Die saad mielies, kafferkoring, pampoene, kalbasse, soetriet e.d.m. is meestal gedokter vir vrugbaarheid en beskerming. Die opbrengs van die graanoes is geberg in grasmandjies, graanputte in die beeskraal, op platforms of in kegelvormige graanhutte. Alhoewel die Swazi van oudsher skape, bokke en honde aangehou het, word die bees tog die hoogste geskat. Dit is simbool van status en rykdom, dit voorsien voedsel en klere, dit dien as vergoeding vir gelewerde diens, dit is by uitstek die huweliksoordraggoedere en die offerdier.

Tradisioneel is 'n strenge arbeidsverdeling op grond van seksverskille gehandhaaf. Die man se belangrikste plig was die oorlog, die jag en die veeversorging. Vroue moes kinders voortbring en versorg, die huiswerk verrig en met hulp van die mans die lande bewerk en die bouwerk verrig. 'n Verdere verdelingsbasis was leeftyd: kinders het na gelang van hulle ontwikkeling en volgens hulle geslag die ouers bygestaan. 
Binne die ongedifferensieerde ekonomiese lewe was daar enkele eksklusiewe en gespesialiseerde beroepe soos dié van smede, en rituele eksperte, veral toordokters en waarsêers. Die smidsberoep het 'n lang vakleerlingskap vereis en baie vermydinge (taboes) meegebring. Verder het hulle die erts gesmelt en gevorm, maar geen diep myne is ontgin nie. Die Swazi maak selfs aanspraak op 'n vroeëre kundigheid van koper- en bronsbewerking, maar dit moes een of ander tyd verlore gegaan het.

Onder die Ngunivolke neem die Swazi 'n unieke plek in vir sover dit die verdeling van politieke mag betref tussen die opperhoof of Ingwenyama (leeu) en die opperhoofsmoeder of Indlovukati (die olifantskoei). Onder die Suid-Afrikaanse Bantoes kan alleen die Venda se aandeel van die makhadzi (stamhoof se oorlede vader se suster of sy eie suster) enigsins hiermee vergelyk word. Hierdie twee figure word met die hoogste respek bejeën. Hulle is gesamentlik verantwoordelik vir die handhawing van wet en orde in die land. Tussen die twee word die magsbalans gehandhaaf. Die Ingwenyama presideer oor die hoogste hof; die Indlovukati oor die tweede hoogste. Die sakrale nasionale voorwerpe is in haar bewaring, maar dit het geen uitwerking sonder sy samewerking nie. Die opvatting bestaan dat die opperhoofsmoeder geen tweede seun mag hê nie. Dit sou 'n bedreiging vorm vir die latere regeerder. Sy is ook nie onderhewig aan die leviraatsinstelling nie.

Die verdeling van mag ten einde absolute heerskappy aan bande te lê, kom ook in 'n ander instelling aan die lig. Wanneer die opperhoof sy amp aanvaar, word twee mans van ongeveer dieselfde ouderdom gekies uit twee bepaalde sibbes en hulle sluit 'n soort bloedbroederskap met die nuwe opperhoof. Hulle behoort nie tot die koninklike familie nie en kan beskou word as verteenwoordigers van die volk. Hierdie tinsila is die opperhoof se belangrikste medestanders: sy oë en ore teen verraad. Verder word hy bygestaan deur raadslede (tindvuna) uit die koninklike krale maar behorende tot die gewone volk. Hierdie tindvuna het 'n sterk invloed op die opperhoof sodat die Swazi beweer: die Inkosi word geregeer deur sy tindvuna.

Origens is daar 'n groot aantal geringer amptenare soos hoofde van regimente, wat almal deur die opperhoof aangewys 
word. Alle amptenare word vir hulle volle leeftyd benoem. Hulle word ook beskou as volksverteenwoordigers. Vervolgens is daar ook twee rade, nl. die licoco of private raad en die ibandla of algemene raad. Die licoco is wesentlik 'n familieraad met enkele buitestaanders maar met die Ingwenyama en die Indlovukati as belangrikste lede.

Vir administratiewe doeleindes was die land ingedeel in distrikte (tive) met 'n politiek-administratiewe struktuur soortgelyk aan dié van die hele land maar onder leierskap van 'n erflike of benoemde hoofman (sithulu) en met sy moeder as deelhebber in die gesag. Die distrikte is verdeeld in wyke met tindvuna as administrateurs daarvan. In alle gevalle speel die element van persoonlike lojaliteit 'n uiters belangrike rol.

Huwelik.

Die Swazi stel die poligine huwelik as ideaal. Dit word gesluit deur onderhandeling tussen twee families en bevestig deur die oordrag van lobola of emabeka. Die emabeka sluit thee spesiale beeste in. Die eerste is bedoel vir die bruid se moeder en word geërf deur haar jongste seun. Die tweede, lugege, word tydens die bruilof geslag, gehalveer en deur die twee partye geëet, waarskynlik om op hierdie wyse eenheid te simboliseer. Die Sothostandpunt van huweliksluiting binne die breër verwantskapsgroep het in hierdie geval blykbaar die Ngunigebruik van vermyding van huwelike met lede van die vader en moeder se sibbes verdring. By die Swazi vind ons ook 'n tweeërlei sororaatsgebruik. In die eerste plek is daar ' $n$ bepaalde voorkeur vir 'n volledige huwelik met die vrou se susters, terwyl daarby die bekende sororaatsgebruik ook gevolg word om ' $n$ ihlanti of plaasvervanger te neem indien die huwelik kinderloos bly.

Religie.

Kennis van 'n opperwese is by die Swazi wel aanwesig maar dit is vaag en word as onbelangrik beskou. Die voorouerverering is die kern van die Swazireligie. Aan die emadloti (voorouergeeste) word groot mag toegeskryf. Sowel vaderlike as moederlike geeste word erken, terwyl daar blykbaar gedifferensieer word m.b.t. hulle funksies $\mathrm{min}$ of meer in oor- 
eenstemming met die bekende sosiale orde. Die vaderlike emadloti staan in verband met die wetlike en morele verpligtinge en die moederlike met die welsyn. Hulle maak hulle wense bekend deur drome en siektes of verskyn in die vorm van slange. Die mamba is die koninklike slang. Daar is geen priesterlike orde nie, die familiehoof tree in hierdie hoedanigheid op.

Die emadloti uord erken in alle belangrike gebeurtenisse en seremonies. Die belangrikste van die nasionale en religieuse rituele is dié van die incwala of seremonie van die eerste vrugte, wat in noue aansluiting by die grafte van die opperhoofde gehou word met offerandes, danksegging en gemeenskapsmaaltyd.

Vier aspekte van die demografiese en etnografiese situasie in Swaziland is m.i. veral belangrik, gesien uit 'n landsontwikkelingsoogpunt:

(a) Alhoewel daar allerlei faktore aan die werk is wat desintegrerend inwerk op die tradisionele sosiokulturele patroon, is dit uit ander toestande en gebeure tog ook duidelik dat die Swazivolk as geheel vandag nog sterk "tradisioneel"gesind is: ekonomies, religieus, kultureel en sosio-polities. 'n Grootskaalse ekonomiese ontwikkeling met sy eise t.o.v. diepgaande wysiginge in die sosio-kulturele lewenshouding en -patroon, sal nie geredelik aanvaar word nie, maar sal eerder deur die dwang van omstandighede - behoefte aan inkomste en lewensmiddele - letterlik moet inslaan. Verwag kan word dat dit aanleiding sal gee tot aansienlike aanpassingsprobleme.

(b) Diametraal teenoor voorgenoemde staan juis die onafwendbare omstandigheidseise. Teenoor die tradisionalisme, veral vir sover dit die ekonomiese en die arbeidsektor betref, moet o.a. rekening gehou word met die bevolkingsaanwas. Die jaarlikse groeitempo van ongeveer 4000 Swazi's oor die afgelope 6 jaar, maak die selfversorgende tradisionele landbouekonomie toenemend ondoeltreffend as heenkome. Terwyl landbouproduktiwiteit, mede deur besproeiingskemas, verhoog sal moet word, moet die houding teenoor vaste loonarbeid ook gewysig word. As dit nie gebeur nie sal die ekonomiese agterstand van die Swazi's relatief toeneem terwyl hulle in hulle eie land in die industriële arbeidsfeer deur immigrante uit naburige, veral Portugese gebiede vervang word. Die resultate hiervan in terme van politieke ontevredenheid en sosiale 
lyding is moeilik voorsienbaar. Die omvang van die probleem moet nie los gesien word van die moontlikheid dat die Republiek om geen ander rede as beskerming van sy eie Bantoebevolking, toenemend minder geneë mag wees om arbeidsen verblyfsvoorregte aan Swazilandse onderdane te verleen nie.

(c) Die toenemende verstedeliking, d.w.s. toetrede tot die nywerheidslewe en -sentrum, is die begin van 'n sosiokulturele stroom wat in die komende jare die nasionale patroon van Swaziland ingrypend gaan beïnvloed en nie sonder aanpassingspyne en -reaksies op die persoonlike, maatskaplike en politieke vlak sal bly nie.

(d) Vir die te verwagte industriële ontwikkeling en verandering in staatkundige status van die gebied, is die Swazivolk, gesien uit 'n onderwysstandpunt, blykbaar nog swak toegerus. Alhoewel daar op die vlak van gewone volksonderwys aansienlike vordering gemaak is en word, kan die gedifferensieerde voorbereiding van leiers bo die algemene vlak, d.w.s. vir die uitvoerende, tegnologiese, professionele, administratiewe, politieke en akademiese sfere eers gebou word op 'n hegte fondament van breë volksonderwys. Dit is 'n proses wat nog baie water in die see sal sien loop.

P.U. vir C.H.O., Potchefstroom.

J. H. Coetzee.

\section{HOOFBRONNE:}

Gt. Britain: Swaziland. Report for 1962. A.M. \& V. 1963.

Kuper, Hilda: The Swazi. I.A.I. London, 1952.

An African Aristocracy. O.U.P. London, 1947.

The Uniform of Colour. W.U. Press, 1946.

Marwick, B. A.: The Swazi. Cambridge, 1940. 